San Jose State University

SJSU ScholarWorks

Master's Theses

Master's Theses and Graduate Research

1993

\title{
Vocational self-esteem and perception of employability of university students with a physical disability : a correlational study
}

Cathleen Marquez

San Jose State University

Follow this and additional works at: https://scholarworks.sjsu.edu/etd_theses

\section{Recommended Citation}

Marquez, Cathleen, "Vocational self-esteem and perception of employability of university students with a physical disability : a correlational study" (1993). Master's Theses. 560.

DOI: https://doi.org/10.31979/etd.sk5w-h6uq

https://scholarworks.sjsu.edu/etd_theses/560

This Thesis is brought to you for free and open access by the Master's Theses and Graduate Research at SJSU ScholarWorks. It has been accepted for inclusion in Master's Theses by an authorized administrator of SJSU ScholarWorks. For more information, please contact scholarworks@sjsu.edu. 


\section{INFORMATION TO USERS}

This manuscript has been reproduced from the microfilm master. UMI films the text directly from the original or copy submitted. Thus, some thesis and dissertation copies are in typewriter face, while others may be from any type of computer printer.

The quality of this reproduction is dependent upon the quality of the copy submitted. Broken or indistinct print, colored or poor quality illustrations and photographs, print bleedthrough, substandard margins, and improper alignment can adversely affect reproduction.

In the unlikely event that the author did not send UMI a complete manuscript and there are missing pages, these will be noted. Also, if unauthorized copyright material had to be removed, a note will indicate the deletion.

Oversize materials (e.g., maps, drawings, charts) are reproduced by sectioning the original, beginning at the upper left-hand corner and continuing from left to right in equal sections with small overlaps. Each original is also photographed in one exposure and is included in reduced form at the back of the book.

Photographs included in the original manuscript have been reproduced xerographically in this copy. Higher quality $6 "$ " 9 9" black and white photographic prints are available for any photographs or illustrations appearing in this copy for an additional charge. Contact UMI directly to order.

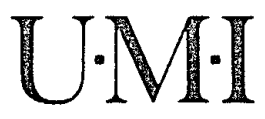

University Microfilms International 

Vocational self-esteem and perception of employability of university students with a physical disability: A correlational study

Marquez, Cathleen, M.S.

San Jose State University, 1993 
. 


\title{
VOCATIONAL SELF-ESTEEM AND PERCEPTION OF EMPLOYABILITY OF UNIVERSITY STUDENTS WITH A PHYSICAL DISABILITY: \\ A CORRELATIONAL STUDY
}

\author{
A Thesis \\ Presented to \\ The Faculty of the Department of Occupational Therapy \\ San Jose State University \\ In Partial Fulfillment \\ of the Requirements for the Degree \\ Master of Science
}

by

Cathleen Marquez

May, 1993 
APPROVED FOR THE DEPARTMENT OF OCCUPATIONAL THERAPY

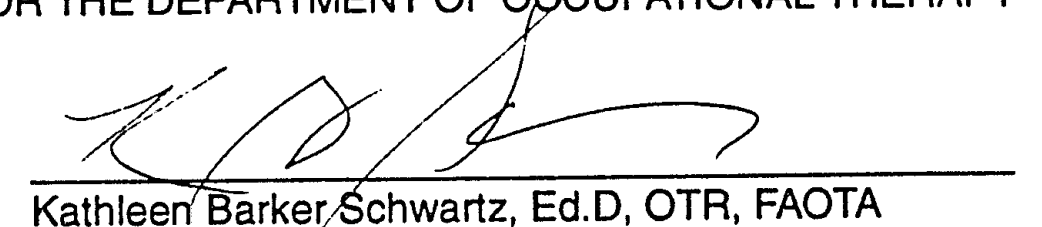

Kathleen Barker Schwartz, Ed.D, OTR, FAOTA

paren Disió Serretet

Karen Diasio Serrett, Ph.D, OTR, FAOTA

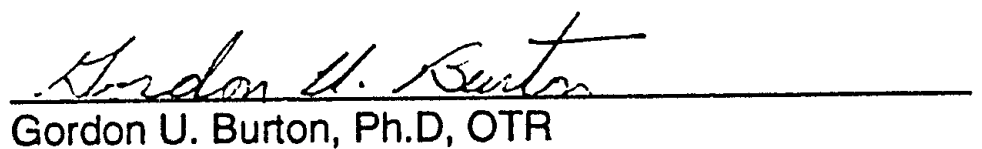

Gordon U. Burton, Ph.D, OTR

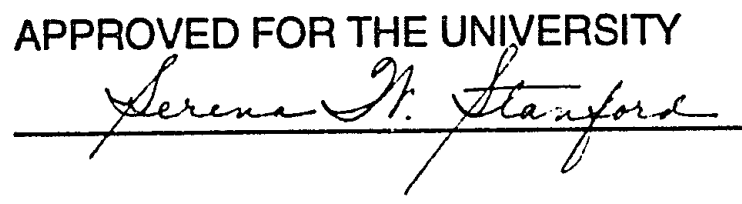




\section{ABSTRACT \\ VOCATIONAL SELF-ESTEEM AND PERCEPTION OF EMPLOYABILITY OF UNIVERSITY STUDENTS WITH A PHYSICAL DISABILITY: \\ A CORRELATIONAL STUDY}

by Cathleen Marquez

The vocational self-esteem and the perceptions of employability of 36 male collegians, 18 with a physical disability and 18 without a disability were investigated to determine: 1) if there is there a difference in vocational self-esteem between these students, 2 ) if there is a difference in perception of obtaining a job after graduation between these students, and 3 ) if there is a correlation between low vocational self-esteem and low perceptions of employability among students with a physical disability. Students completed a questionnaire which included the Modified Rosenberg Self-Esteem Scale-Situational (MRSE-SIT) (Klein, 1985) which assesses vocational self-esteem. They also participated in an in-person interview which assessed their confidence level and expectations of obtaining a job after graduation. Results showed no significant difference between groups on vocational selfesteem and perception of employability. No correlation was found between vocational self-esteem and perception of employability among students with a physical disability. 


\section{ACKNOWLEGEMENTS}

Thanks to God in whom "all things are possible".

Special thanks to the following individuals for their support and assistance in completing this thesis:

...to Advisor Dr. Kathleen Schwartz for the ceaseless encouragement, support and assistance from the beginning to the end. ... to Drs. Lela Llorens, Karen Diasio Serrett and Gordon Burton for reviewing and providing excellent feedback on the thesis. ...to Marty Schulter and the staff at the Disabled Students Services for assistance with obtaining students for the study. ... to statisticians Therese Louie and Robert Gennaro for your expertise in handling the data. ... to all the students who participated in the study for taking time out of their busy schedules to share perceptions on work and employment. ...to my dear friends Jim "Focus" Goddard and Robert "Just Do It" Gennaro whose supportive words helped me to refocus and be persistent in completing the thesis. Last but not least... to my family, Stephen, and friends for your encouragement, and patience. ... I love you dearly! 


\section{TABLE OF CONTENTS}

$$
\text { page }
$$

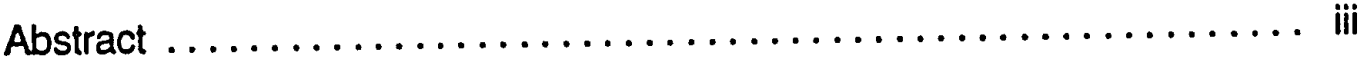

Acknowledgements ............................ iv

Table of Contents .............................. v

List of Tables................................. viii

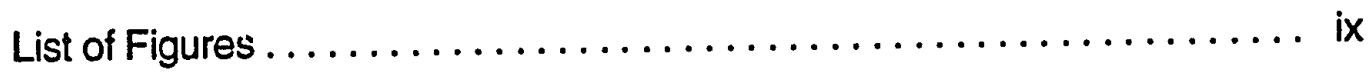

CHAPTER 1: INTRODUCTION........................ 1

Purpose................................. 1

Statement of the Problem $\ldots \ldots \ldots \ldots \ldots \ldots \ldots \ldots \ldots, 1$

Questions .............................. 3

Hypotheses............................. 4

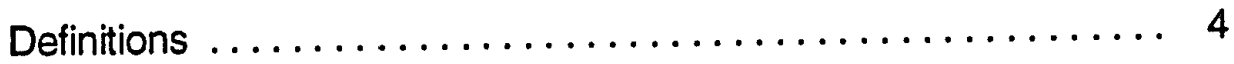

Conceptional Definitions $\ldots \ldots \ldots \ldots \ldots \ldots \ldots, 4$

Operational Definitions .................... 5

Assumptions ............................ 5

Limitations $\ldots \ldots \ldots \ldots \ldots \ldots \ldots \ldots \ldots \ldots \ldots, 6$

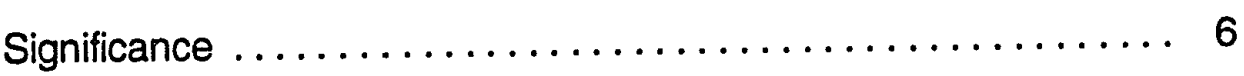

CHAPTER 2: LITERATURE REVIEW .................. 7

Situational Self - Esteem ..................... 7 
Perceptions of Others Toward People with a Disability ...... 8

Person-Environment-Performance Frame of Reference ...... 10

Role of the Occupational Therapist in Vocational

Rehabilitation ........................... 10

Summary ............................... 11

CHAPTER 3: RESEARCH METHOD $\ldots \ldots \ldots \ldots \ldots \ldots \ldots \ldots \ldots \ldots$

Subjects.............................. 13

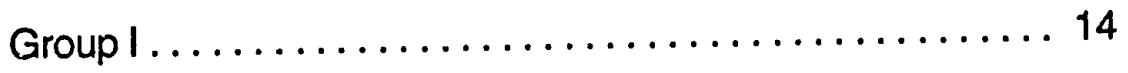

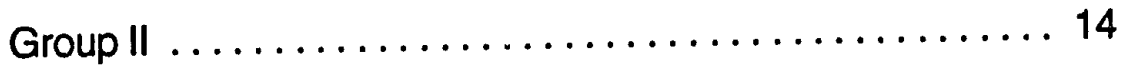

Instruments ............................... 14

Questionnaire ......................... 14

Interview ............................ 15

Procedure ................................ 16

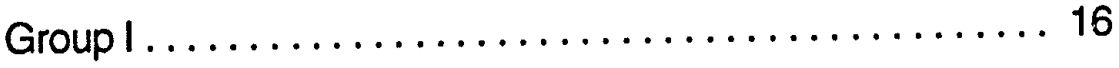

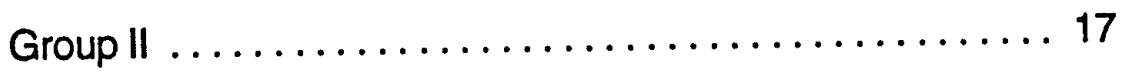

CHAPTER 4: DATA ANALYSIS, RESULTS, AND SUMMARY ...... 19

Introduction ............................... 19

Demographics............................ 19

Results................................. 20

Vocational Self-Esteem ................... 20

vi 
Perception of Employment . . . . . . . . . . . . 23

Confidence Level and Perception of Employment ..... 25

Additional Factors . ...................... 26

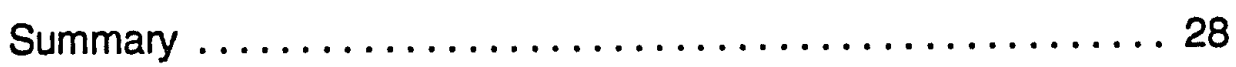

Implications and Recommendations . . . . . . . . . . . 27

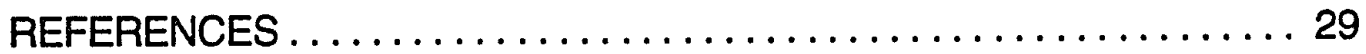

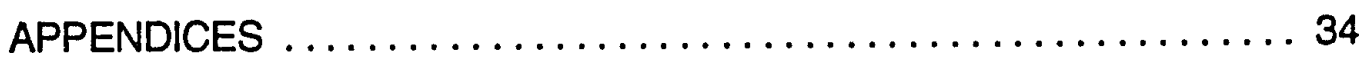

Questionnaire - Appendix A ..................... 34

Interview Questions - Appendix B ................. 36

Consent Form - Appendix C . . . . . . . . . . . . . 38

vii 


\section{LIST OF TABLES}

page

Table 1. Demographics for Students With and Without a Physical Disábility

Table 2. Responses to Interview Question Regarding Perceived Factors that Inhibit Employment 


\section{LIST OF FIGURES}

page

Figure 1. MRSE-SIT Mean Scores for Students With and

Without a Disability

22

Figure 2. Mean Score of Level of Confidence for Obtaining

Employment after Graduation of Students With and

Without a Disability

24

Figure 3. The Level of Confidence for Obtaining

Employment Against the MRSE-SIT Score

25 


\section{CHAPTER 1 \\ INTRODUCTION}

\section{Purpose}

The purpose of the study was to explore the vocational selfesteem and perception of employability of University students with a physical disability and other factors which may hinder a person from gaining employment.

\section{Statement of the Problem}

College students with a physical disability often have difficulty obtaining employment after graduation. Although the number of individuals with disabilities entering competitive employment is increasing, people with disabilities continue to remain out of the work force in numbers disproportionate to their prevalence in the population (Greenwood \& Johnson, 1987). An estimated $33.6 \%$ of the 13.3 million working age adults with work disability are employed in the labor force and $15.6 \%$ are unemployed while $78.5 \%$ of 140.9 million adults with no disability are employed and only $6.8 \%$ are unemployed (Kraus \& Stoddard, 1989). Studies show that the employment prospects of the disabled are improved with a college education (Fichten \& Amsel,1986; Lonnquist, 1979; and Schriner \& Roessler, 1990). Yet even with higher education, college graduates with a disability still have difficulty obtaining employment. Sampson (1981) stated, "Disabled college graduates take much longer than their able-bodied peers to obtain employment, and all 
too frequently end up unemployed or underemployed. What can be done to insure success?" (p. 127).

Research on people with a disability and employment reveals both external and internal factors that contribute to unemployment (Greenwood \& Johnson, 1987; Bowman, 1987; Colorez \& Geist, 1987); Parker, 1980; Poole, 1987; Sampson, 1981). External factors are environmental, societal, or economical factors such as architectural barriers, transportation, attitudes toward the disabled, and disability benefits. Internal factors are intrinsic, intrapersonal or self-imposed factors such as vocational self-esteem, attitudes toward work, perceptions of employment, and job preparation. For the past few decades, legislators, educators and researchers have examined and implemented laws and/or programs that address external issues (Bolton, Roessler, Greenwood, Hinman, \& Little, 1983; Goodman-Lavey \& Lisoni, 1992). Yet, little research has been conducted on internal factors. Two factors of interest are vocational self-esteem and perception of employability.

People with a disability are perceived as having less confidence and self-esteem than people without a disability (Fichten, Robillard \& Judd, 1989). Consequently, collegians with a physical disability are often perceived as having low self-esteem regarding work or low confidence about gaining employment. Are these perceptions valid? Does their vocational self-esteem influence their perception of employability? An 
investigation is needed to give insight to the perceptions and concerns of collegians with a disability in regard to work and employability.

"The specific aims of the occupational therapy ... are to assist the individual to recover or to develop competence in the physical, psychological, social, and economic aspects of daily living and to provide opportunities to learn those skills needed for adaptation in educational, work, home, and community environments" (Ellsworth, Davy, Mitcham, Parkin, \& Presseller, 1979, p. 882). By implementing these aims from a person-environment-performance framework, an occupational therapist can better assist collegians with a physical disability in obtaining work through clearer understanding of factors that may inhibit students from becoming employed.

\section{Questions}

The following questions were studied.

1. Is there a difference in the vocational self-esteem scores of students with a physical disability and students without a disability?

2. Is there a difference in the level of confidence for obtaining employment after graduation between students with a physical disability and students without a disability?

3. Do disabled students who achieve a low score on the Modified Rosenberg Self-Esteem Scale-Situational (MRSE-SIT) also have a low perception of employability according to interview? 
4. What factors do students with a physical disability perceive as influencing their ability to obtain employment?

Hypotheses

The investigator hypothesized:

1. The MRSE-SIT scores of students with a physical disability will be lower than the scores of students without a disability.

2. The confidence level for finding a job after graduation of students with a disability will be lower than of students without a disability.

3. Students with a physical disability having a low MRSE-SIT score will also demonstrate low confidence of employability.

Definitions

\section{Conceptual Definitions}

Perception of employability: The opinion, sense, or outlook of one's ability to obtain a job.

Physical Disability: A neurological, orthopedic, or visual impairment; such as paraplegia, polio, and blindness respectively.

Self-Esteem: An important metadimension of self-concept (Super, Strarishevsky, Matlin, \& Jordon, 1963), the individual's evaluation of the self that is based on some characteristic (Rosenberg,1965), a personal judgment of worthiness 
expressed in one's attitudes about the self (Coopersmith, 1967), and the individual's general evaluation of himself (Korman, 1966).

Vocational self-esteem: An evaluation of oneself regarding an occupation or chosen profession.

\section{Operational Definitions}

Perception of Employability: The level of confidence of obtaining a job in one's chosen profession expressed by an interview question rated on a 4-point Likert scale.

Students with a physical disability: Male junior, senior or graduate students attending San Jose State University and registered with the Disabled Student Services (DSS).

Vocational self-esteem: Self-esteem that is exclusively related to one's career interest or chosen profession as measured by Klein's Modified Rosenberg Self-Esteem Scale Situational.

\section{Assumptions}

The following assumptions were made:

1) Subjects will answer questions truthfully.

2) The Modified Rosenberg Self-esteem Scale Situational (MRSE-SIT) effectively measures vocational self-esteem.

3) The students without a disability were truthful in disclosure. 


\section{Limitations}

The following were limitations of this study:

1) The sample size was small $(\mathrm{N}=36)$.

2) The sample was delimited to males.

3) The sample was specific. Results cannot be generalized to all students with a physical disability.

4) The questionnaire and interview questions were not pilot tested.

5) The validity and reliability of the MRSE-SIT are unknown.

\section{Significance}

The results provide occupational therapists with a clearer understanding of the disabled student's vocational self-esteem and perception of employability so that the therapist can identify problematic issues and therefore can better assist students to improve their employability skills. 


\section{CHAPTER II}

\section{LITERATURE REVIEW}

Little research focuses on the vocational self-esteem and perception of employability of collegians who have a disability. Examination of these factors are needed to gain insight into their perceptions and concerns toward work and employability.

Research on situational self-esteem, perceptions of others toward college students with a disability, the Person-Environment-Performance framework, and the role of the occupational therapist in vocational rehabilitation will be discussed to present the rationale and the theoretical perspective for the study.

\section{Situational Self-Esteem}

Research provides evidence for the relationship between selfesteem and vocational behavior (Coopersmith, 1967; Klein, 1985). Although theory implies that self-esteem tends to shift from situation to situation, most self-esteem measures assess global self-esteem (Marganoff, 1978). Marganoff examined the differential influence of situational (vocational) self-esteem versus global self-esteem on high school students. She found vocational self-esteem to differ significantly from global self-esteem. "...the use of the construct of vocational selfesteem permitted differences to emerge which did not show up when global self-esteem was considered" (Klein, 1985, p.74).

Klein (1985) examined the effects of vocational self-esteem on the 
employment status of severely psychiatrically disabled clients. She theorized that vocational self-esteem would be positively and significantly related to employment status. This expectation was not confirmed. She explained that in a psychiatrically disabled sample where inadequate self-esteem is a characteristic problem, situational self-esteem may not be as useful as a measure of global self-esteem. Klein stated also that situational self-esteem may be a useful construct for a non-psychiatric population.

Based on Marganoff's and Klein's studies, it was anticipated that the vocationally specific self-esteem measure would yield data which would reveal a stronger relationship between self-esteem and employment of college students with a physical disability. Yet, research on the vocational self-esteem of collegians with a physical disability could not be found and a longitudinal study on employment status of these students was not feasible. Therefore, this preliminary study was conducted to assess the level of vocational self-esteem and to gain insight to the student's perceptions of employability.

Perceptions of Others Toward Collegians with a Disability

Numerous studies have compared trait attributes and stereotypes of college students with and without a disability (Benshoff, Kroeger \& Scalia, 1990; Beail, 1986; Fichten \& Amsel, 1986; Fichten, et al, 1989; Parker, 1980; Schriner \& Roessler, 1990; Weinberg-Asher, 1976). These investigations reveal that people perceive collegians with a disability 
as different or as having opposite traits on social-emotional, attitudinal and physical dimensions. Weinberg-Asher (1976) found that students with a physical disability were seen as less intelligent, less confident, less happy, and less physically attractive than persons without a disability. Fichten, et al (1989) also found that they were perceived as having less confidence and self-esteem.

According to theories that self-esteem is developed by adoption of others' view or by interaction with the social world, people with a disability should have lower self-esteem than individuals without a disability (Rosenberg, 1979; Rosenberg \& Kaplan, 1982). Fichten, et al. (1989), however, revealed different findings. She compared the selfesteem (Real Self/ldeal Self/Reflected Self) of 32 college and university students with a physical disability and 221 without a disability. The study showed that students with a disability did not differ significantly from students without a disability on any of the measures administered on selfesteem.

Weinberg-Asher's study (1976) also revealed that collegians are much like their college peers. The self-ratings of 139 University students with a disability (sensory, motor, or other) and without a disability were compared on a variety of personality traits and attitudes. This study suggested that "disabled people perceive themselves in much the same way that abled-bodied people perceive themselves..." (p. 19).

A person's perception toward an individual can impact not only 
how he views that individual but also can affect the individual's selfperception and performance. Yerxa (1992) acknowledged society's limiting perspective toward people with a disability and advocated for occupational therapist to foster a positive perspective. She believes that occupational therapy's optimistic view has potential to influence the skills of people with a disability and societal attitudes toward such people.

Person-Environment-Performance Frame of Reference The person-environment-performance framework was developed by Christainsen and Baum (1991).The framework is distinct from other frameworks in that it identifies additional individual and environmental factors which impact performance. According to Christiansen (1991), "This framework highlights the necessity of considering the environment, the individual, and the occupations relevant to an individual's life when trying to understand what motivates and facilitates performance capabilities" (p. 38).

Role of the Occupational Therapist in Vocational Rehabilitation

Occupational therapy has been irvolved in the vocational rehabilitation movement since the passage of the Federal Industrial Act of 1923 , which required the inclusion of occupational therapy in all general hospitals dealing with industrial accidents and illness (Ellsworth, Davy, Mitcham, Parkins, \& Presseller, 1980). With the passage of Public Law 94-142, the Education for All Handicapped Children Act of 1975, the role of occupational therapists expanded into the community and 
schools. Under this legislation, therapists provided service to children in primary and secondary schools or up to 21 years of age.

In 1984, the Carl D. Perkins Vocational Education Act (Public Law 98-524) was passed by Congress to improve the quality of vocational education programs and services for students with disabilities (Mitchell, Rourk, \& Schwarz, 1989). This legislation ensured that students with disabilities have the same vocational educational services available to them as do nondisabled students.

Under the Rehabilitation Act of 1973 and Public Law 94-142 colleges are required to provide supportive services for students with a disability. Literature reveals that some community and state college programs employ occupational therapists to assist individuals who have a disability with the transition to work (Schelly, 1990; Burnett \& Yerxa, 1980).

\section{Summary}

Since people with a disability are often viewed as having less confidence and self-esteem than people without a disability, it would seem that collegians with a disability would have less vocational selfesteem and confidence of employability than collegians without a disability. Theory that self-esteem is developed by adoption of others' view or by interaction with the social world suggests that people with a disability should have lower self-esteem than individuals without a disability (Rosenberg, 1979; Rosenberg \& Kaplan, 1982). However, 
Fichten et al (1989) revealed that people with disabilities described themselves in the same way as did their peers without disabilities.

Persons who have a disability are often the most expert sources of information about their personal life situations. The literature on vocational self-esteem and perception of employability provided insight into factors that may inhibit persons with a disability from obtaining employment. The Person-Environment-Performance framework encompasses both human and environmental factors that influence performance. 
CHAPTER III

RESEARCH METHOD

The vocational self-esteem and perception of employability of 18 collegians with a disability and 18 collegians without a disability were investigated in this a correlational study. The purpose was to determine if there is a difference between the two groups, and if students with a disability who have low vocational self-esteem also have low perception of employability. Data were collected through a questionnaire and an interview.

\section{Subjects}

The sample population was systematically selected on the following criteria: 1) class standing - junior, senior, or graduate student; 2) gender - male; and 3) physical status - with a physical disability or without a disability.

Junior, senior, and graduate students were chosen because the study focused on collegians who were beginning to explore or seek employment in their major or career interest. Scores from Freshmen and Sophomores who are not sure of their major or career goal could have skewed the data. Gender was limited to males because gender has more of an influence on self-perception than does a physical disability. Wienberg-Asher (1976) found greater differences in self-reports between males and females than between the "abled-bodied" and the "disabled." Students with a physical disability comprised Group I. Students without 
a disability comprised Group II. The latter was the control group.

\section{Group I}

Group I was chosen from a composite list of 62 students. This list was compiled through the assistance of the Disabled Students Services Program (DSSP) at San Jose State University (SJSU). Students who met the minimum requirements $(\underline{N}=41$ ) were contacted by letter and then by a follow-up telephone call. Of the 41 possible candidates, 18 students confirmed participation.

\section{Group II}

The subjects were obtained through the assistance of several SJSU professors who teach upper division general education and graduate courses. Upon confirmation from the professor, the students of the selected courses were informed about the study (the benefits, procedure, risk, rights as a participant) then handed a questionnaire to complete (Appendix A). Of the 209 students who participated in the survey, 83 students met the criteria and provided a telephone number as indication that they also were willing to complete the interview. 18 of the 83 students were then randomly selected by rolling dice.

Instruments

\section{Questionnaire}

A questionnaire was used to obtain information regarding demographics, vocational self-esteem, attitude toward work, and perception of employability (see Appendix A). Included in the 
questionnaire is the Modified Rosenberg Self-Esteem Scale SituationalMRSE-SIT (questions 11 - 21). This 11-item instrument (Klein, 1985) was used to measure vocational self-esteem. The MRSE-SIT is comprised of the 11-item Modified Rosenberg Self-Esteem Scale (MRSE) with the phrase, "When I think about working..." prefacing each statement. The responses were chosen from a Likert scale (strongly agree, agree, disagree, strongly disagree). For the present study, points ranging from 1 to 4 were assigned to each response which indicated low to high vocational self-esteem.

The questionnaire was modified for Group II by eliminating questions pertaining to disability.

Empirical evidence of reliability and validity for the MRSE-SIT is unavailable. However, Klein (1985) stated that the instrument has considerable face validity. Neither questionnaire were pilot tested due to limited time and group I subjects.

\section{Interview}

The interview consisted of open and close ended questions regarding work experience, expectations of obtaining a job after graduation, and factors that may influence employment (See Appendix B). The question "How confident are you about obtaining employment after graduation..." was used to measure perception of employability. First the subjects responded to the question then they were asked to respond on the scale 1 - not confident , 2- somewhat confident, 3-very 
confident, and 4- highly confident. The interview was adjusted for Group II by modifying the questions directed to individuals with a disability toward individuals without a disability.

A self-report method (the questionnaire and interview) was selected because persons with disabilities are often the most expert sources of information about their personal life situations. They can provide accurate data to understand their concerns regarding employment. Also, self-report is a reliable method of determining needs because it reduces the "specialist effect" in which a professional identifies a person's needs in terms of his or her own ability to apply treatment (Burnett \& Yerxa, 1980). The interview was conducted inperson to gain greater insight into the perceptions and the personality of the subjects which could not be obtained from a questionnaire. It enabled the evaluator to ask subjects to explain or elaborate on unclear responses and to observe their body language such as hand gestures, eye contact, and volume of speech.

\section{Procedure}

\section{Group I}

On a scheduled day, the investigator met with the students individually. The student received information regarding his right as a research subject and signed a consent form (Appendix $C$ ). Next, the student received the following verbal instruction: "Please answer every question giving the answer which best describes you. Work as rapidly 
and as carefully as you can. Do not spend too much time on any one question." They then completed the questionnaire. Students who were unable to complete the form due to their physical disability received assistance from the investigator who acted as the scribe or reader. Completion of the consent form and the questionnaire required about 10 to 15 minutes.

After the subject completed the questionnaire, the investigator gave the following interview instructions: "The purpose of this interview is to obtain information regarding your work skill, career goals, and perception of employment. Please answer in a way that best describes yourself and your experiences. Your reponses will be tape recorded and the information will be kept confidential." All of the students were asked the same set of questions. Observations of the students were recorded on paper during the interview. The interview process took approximately 20-30 minutes.

\section{Group II}

On a scheduled day, the investigator went to a selected class. The questionnaire was administered with the same verbal instructions that were given to Group I. However, the students were informed that by completing the questionnaire, they were also giving their consent for participating in the study.

Of the 114 total students who completed the questionnaire, 83 students voluntarily gave their telephone numbers indicating that they 
were willing to partake in the follow-up interview portion of the study.

From the 83 candidates, 18 students were selected by rolling dice. They were contacted by telephone to set up an interview. Two students declined the interview due to busy schedules so two more students were randomly selected by rolling the dice. One student did not keep his appointment and was also replaced. The interview was administered the same as in Group I except questions pertaining to disability were rephrased without reference to disability. The interview process took approximately 15 - 25 minutes.

When each set of interviews was completed, the investigator transcribed the information from the cassettes to paper. 


\section{CHAPTER 4}

\section{DATA ANALYSIS, RESULTS, AND SUMMARY}

Introduction

The vocational self-esteem and perception of employability of 36 male San Jose State University (SJSU) students (18 with a physical disability and 18 without a disability) were investigated in this study. All 36 students completed a questionnaire containing the Modified Rosenberg Self-Esteem Scale-Situational (MRSE-SIT) and an interview regarding their work experience, career goals, expections of obtaining a job and factors that may enchance or hinder employment. The demographic data, MRSE-SIT scores, and confidence scores of employability of the students are presented in this chapter. Findings regarding research questions and hypotheses are discussed.

\section{Demographics}

Group I consisted of the students who have physical disability. Of this group, 8 were juniors (44\%), 7 were seniors (39\%), and 3 were graduate students (17\%). The mean age of the students was 31 years old. The type and frequency of the disabilities were: spinal cord $(\underline{n}=5)$, visual impaired $(\underline{n}=6)$, polio $(\underline{n}=2)$, cerebral palsy $(\underline{n}=1)$ and orthopedic $(\underline{n}=5)$. The students classified the severity of the disability: $17 \%$ as severe $(\underline{n}=3) ; 56 \%$, moderate $(\underline{n}=10) ;$ and $28 \%$, mild $(\underline{n}=5)$. The age at which the disability was acquired showed: $28 \%$ between the ages of birth to 10 years $(\underline{n}=5) ; 33 \%, 11$ to 20 years $(\underline{n}=6), 17 \%, 21$ to 30 years 
( $\underline{n}=3)$; and $22 \%, 31$ and up ( $n=4)$. Seventy-two percent of the students were working on their first degree while twenty-eight percent had returned to school to obtain a second degree or to make a career change because of their disability.

Group II consisted of students without a disability. Of the group, 10 were juniors (56\%), 6 were seniors (33\%) and 2 were graduate students (11\%). The mean age of the group was 24 years old. Ninetyfour percent of these students were working on their first degree while six percent were back in school to obtain a second degree or to make a career change. See Table 1 for a comparison of the Groups I and II.

Results

\section{Vocational Self-Esteem}

1. Is there a difference in vocational self-esteem (MRSE-SIT scores) of students with a physical disability and students without a disability?

Figure 1 illustrates the MRSE-SIT mean scores for students with a physical disability (Group I) and students without a disability (Group II). Data show that the mean score for Group I was $3.56(S D=0.42)$ and the mean score for Group II was $3.48(S D=0.46)$. A t-test showed no significant difference between the MRSE-SIT mean scores of students with a physical disability and students without a disability $(t)(35)=.59$, $\underline{p}<.60)$. 
Table 1

Demographics for Students With and Without a Physical Disability

\begin{tabular}{cc}
\multicolumn{2}{c}{ Group $^{\text {W }}$} \\
\hline With & Without \\
Disability & \\
\hline
\end{tabular}

\begin{tabular}{lcc}
\hline Age & & \\
Mean years & 31 & 24 \\
Grade Level & & \\
Junior & & \\
Senior & $44 \%(8)$ & $56 \%(10)$ \\
Graduate & $39 \%(7)$ & $33 \%(6)$ \\
& $17 \%(3)$ & $11 \%(2)$ \\
Marital Status & & \\
Single & & \\
Married & $56 \%(10)$ & $78 \%(14)$ \\
Divorce & $33 \%(6)$ & $22 \%(4)$ \\
Major & $11 \%(2)$ & $0 \%(0)$ \\
Applied Arts \& Sciences & & \\
Business & & $17 \%(3)$ \\
Education & $28 \%(5)$ & $0 \%(0)$ \\
Engineering & $17 \%(3)$ & $0 \%(0)$ \\
Humanities \& Arts & $6 \%(1)$ & $44 \%(8)$ \\
Sciences & $11 \%(2)$ & $22 \%(4)$ \\
Social Science & $17 \%(3)$ & $11 \%(2)$ \\
Undecided & $11 \%(2)$ & $6 \%(1)$ \\
Career Change & $6 \%(1)$ & $0 \%(0)$ \\
First & $6 \%(1)$ & \\
Second & & $94 \%(17)$ \\
No response & & $6 \%(1)$ \\
\hline
\end{tabular}

$a_{n}=18$ for $\theta$ ach group 


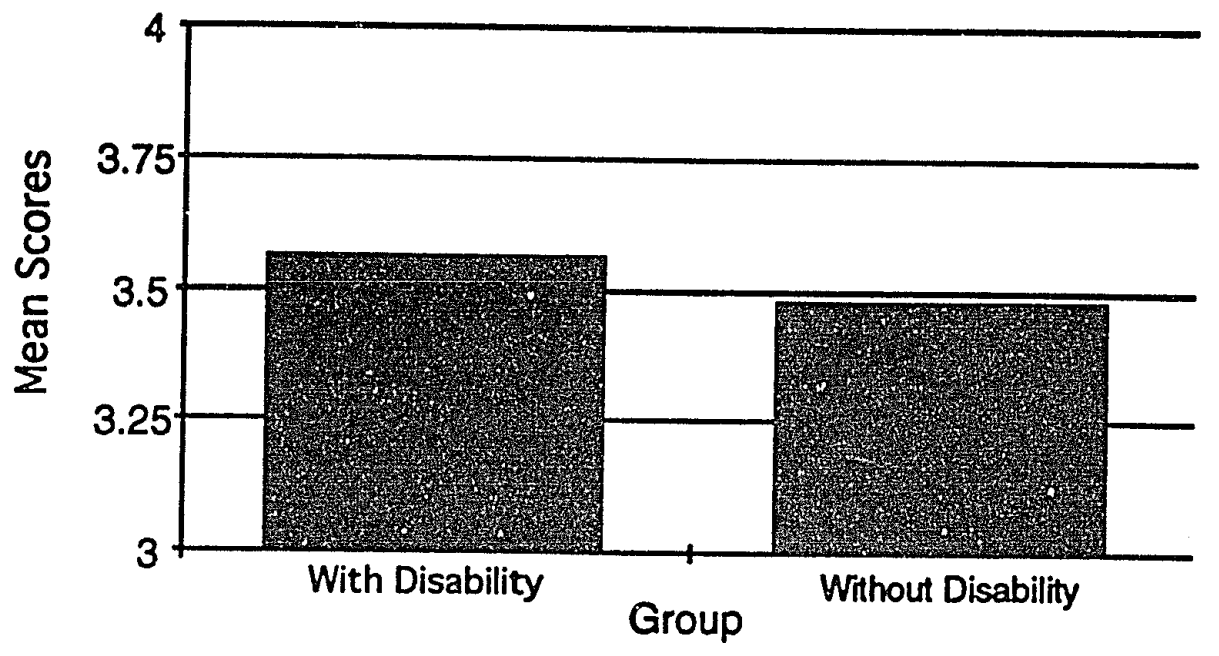

Figure 1

MRSE-SIT Mean Scores for Students With and Without a Disability 


\section{Perception of Employment}

2. Is there a difference in the level of confidence for obtaining employment after graduation between students with a physical disability and students without a disability?

Figure 2 illustrates the mean scores Group I and II. Data show that the mean score for Group I was $3.44(S D=0.71)$ and the mean score for Group II was $3.39(S D=0.70)$. A t-test showed no significant difference between students with a physical disability and students with no disability $(t(.06)=.59, \underline{p}<.25)$ in the level of confidence for obtaining employment after graduation.

\section{Confidence Level and Perception of Employment}

3. Do disabled students who have a low MRSE-SIT score also have a low level of confidence of obtaining a job after graduation?

Figure 3 illustrates the scores and the level of confidence of obtaining employment for students with a physical disability. Data show only one student with a low MRSE-SIT score (2.9); yet, his level of confidence of obtaining a job after graduation is 3.0. According to the Pearson correlational test, there was no significant relationship between the MRSE-SIT mean scores of students with a physical disability (correlation coefficient is 0.36 and $p=0.14$ ). The probability of this occurring by chance is less than $15 \%$. Even when the correlation coefficients of all students were examined, there was no correlation 


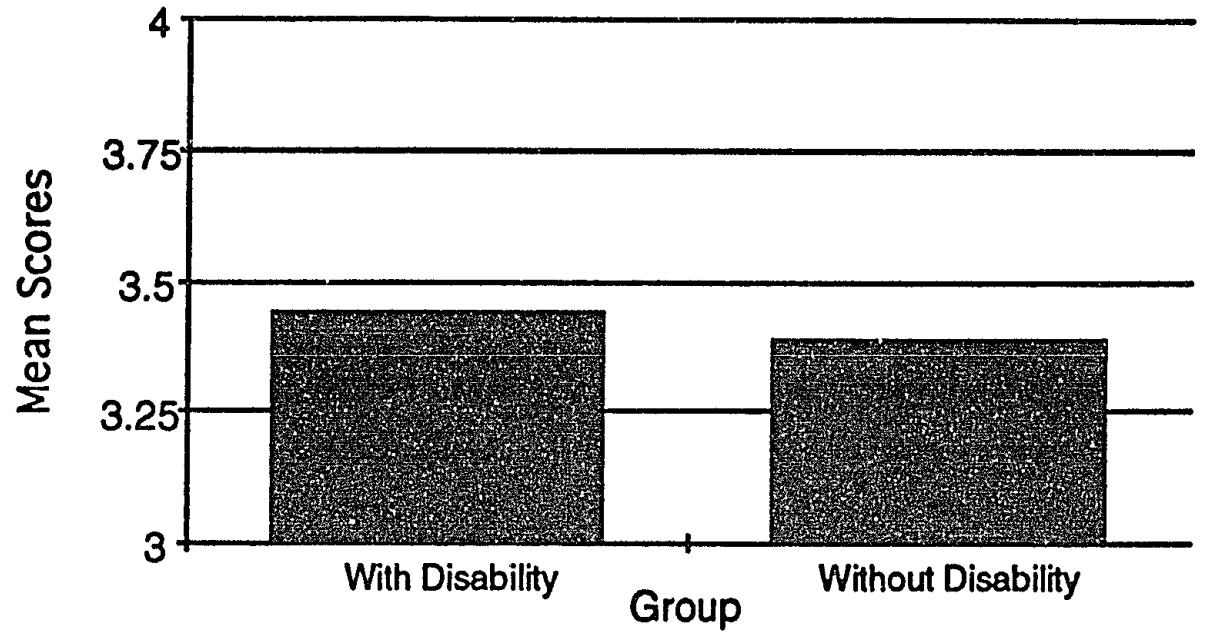

Figure 2

Mean Score of Level of Confidence for Obtaining Employment after Graduation of Students With and Without a Disability 


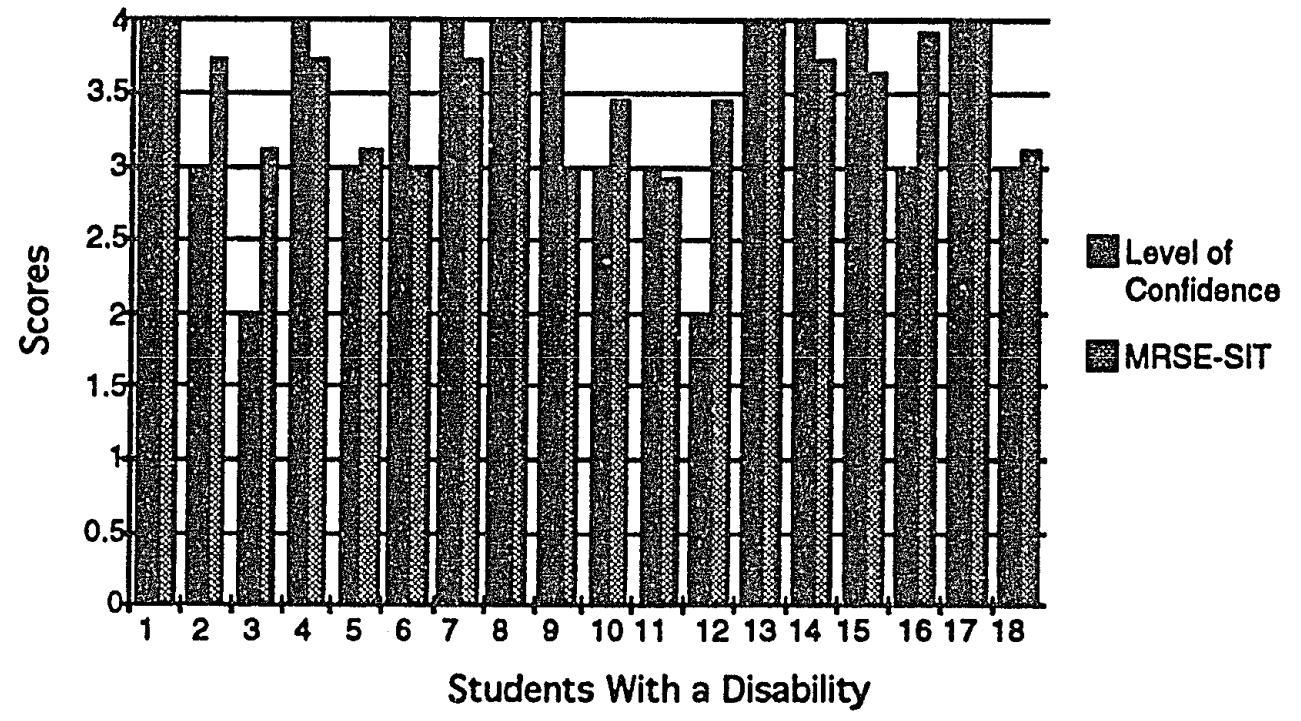

Figure 3

The Level of Confidence for Obtaining Employment Against the MRSESIT Score 
between the confidence level score and vocational self-esteem score $(0.28, p<0.10)$.

\section{Additional Factors}

4. What factors do students with a physical disability perceive as inhibiting their ability to obtain employment?

Table 2 shows responses to the interview question. The most common inhibitors expressed by Group I were the disability, discrimination or negative attitudes, "Myself," lack of transportation, and lack of a degree.

\section{Summary}

The vocational self-esteem and perception of employability of 36 male University students with and without a physical disability were examined to determine if there is a difference in vocational self-esteem and perception of employability between these two groups of students. The results revealed no significant difference in the level of vocational self-esteem or level of confidence for employability between the two groups. Also, the results revealed that among students with a disability, there was no significant relationship between vocational self-esteem and perception of employability. Factors which they perceived may inhibit them from obtaining employment were the disability, discrimination or negative attitudes of others, themselves, lack of transportation, and lack of a degree. 
Table 2

Responses to Interview Question Regarding Perceived Factors that Inhibit Employment

Disability: "My disability," "How much I can take on," "My physical strength"

Negative/Discrimination: "Prejudice," "Negative attitude of people," "Employers look at me as disabled."

Self: "Myself," "Sluggishness about talking with people, getting an internship and finding what is out there."

Transportation:

"I can't drive."

No Degree:

"Lack of degree" 
Implications and Recommendations

People with a disability perceive themselves in much the same way as able-bodied persons. This perspective is contrary to society's view that people with a disability differ from people without adisability. Occupational therapists must not assimilate society's limiting perspective. Therapist ought to foster a positive perspective of persons with a disability. One's perceptions toward an individual can impact not only how one looks at and works with that individual but also can affect the individual's self-perception and performance. Therefore, therapists need to be aware of the images they have and project onto people with a disability. Yerxa (1992) advocates that therapists must present a hopeful perspective of people with a disability "...occupational therapy's optimistic view of people will have the potential to influence both the skills and the competencies that people who are disabled develop and societal attitudes toward such people (p. 81)."

The Americans with Disabilities Act (ADA) stipulates that qualified individuals with a disability be given equal consideration for employment. Occupational therapist ought to focus on issues that insures or enhances students chance to be a qualified candidate. Collegians with a disability identified several factors that might inhibit them from becoming employed. Additional research is needed on these factors to assess their influence on students to obtain employment. 


\section{REFERENCES}

Beail, N. (1983). Physical disability: The self and the stereotype. International Journal of Rehabilitation Research, 6(1), 56-57.

Benshoff, J. J., Kroeger, S. A., \& Scalia, V. A. (1990). Career maturity and academic achievement in college students with disabilities. Journal of Rehabilitation, 56(2), 40-44.

Bolton, B., Roessler, R., Greenwood, R., Hinman, S., \& Little, N. (1983). A research strategy to enhance the employability of handicapped persons. Journal of Applied Rehabilitation Counseling. 14(4), 3037.

Bowman, J. T. (1987). Attitudes toward disabled persons: Social distance and work competence. Journal of Rehabilitation, 53(1), 41-44.

Burnett, S. E. \& Yerxa, E. J. (1980). Community-based and college-based needs assessment of physically disabled persons (community, college, physical disability, needs, schools). American Journal of Occupational Therapy, 34, 201-207.

Christiansen, C. (1991) Occupational therapy intervention for life performance, Chap 1. In Christiansen, C. \& Baum, C. (1991). Occupational therapy: Overcoming human performance deficits. Thorofare, N.J.: Slack, pp. 26-31.

Colorez, A. \& Geist, G. O. (1987). Rehabilitation vs. general attitudes toward hiring disabled persons. Journal of Rehabilitation, $53(2)$, 44-47. 
Coopersmith, S. (1967). The antecedents of self-esteem. San Francisco:

S. N. Freman.

Ellsworth, P., Davy, J., Mitcham, M., Parkins, J., \& Presseller, S. (1980).

The role of occupational therapy in the vocational rehabilitation process. American Journal of Occupational Therapy, 34, 881-883.

Fichten, C. S., \& Amsel, R. (1986). Trait attributions about college students with physical disability: Circumplex analyses and methodological issues. Journal of Applied Social Psychology, 16(5), 410-427.

Fichten, C. S., Robillard, K., \& Judd, D. (1989). College students with physical disabilities: Myths and realities. Rehabilitation Psychology, 34(4), 243-257.

Greenwood, R., \& Johnson, V.A. (1987). Employer perspectives on workers with disabilities. Journal of Rehabilitation, 53(3), 37-45.

Goodman-Lavey, M. \& Lisoni, A. M. (1992) The americans with disabilities act. OTAC Newsletter, 17(10), 7-8.

Klein, M. E. (1985). Influences on the employment status of psychiatrically disabled. Dissertation Abstracts International, 47, 1833A. (University Microfilms No. 85-24222).

Korman, A. L. (1978). Self-esteem variable in vocational choice. Journal of Applied Psychology. 50, 479-486. 
Kraus, L. E. \& Stoddards S. (1989). Chartbook on disability in the U.S. An Info Use Report. Washington D.C.: U.S. Institute on Disability and Rehabilitation Research. Prepared for U.S. Department of Education.

Lonnquist, D. E. (1979). Employment rates among severely physically disabled and nondisabled college graduates and dropouts. Journal of Applied Rehabilitation Counseling, 10(1), 24-27. Marganoff, P. P. (1978). Readiness for career planning: A function of sex and vocational self-esteem. Unpublished doctoral dissertation, Rutgers University. In Klein, M. E. (1985). Influences on the employment status of psychiatrically disabled. Dissertation Abstracts International, 47, 1833A.

Mitchell, M., Rourk, J. D., \& Schwarz, J. (1989). A team approach to prevocational services. American Journal of Occupational Therapy, 43, 378-383.

Parker, J. M. (1980). Attitudes of Employers in education and manufacturing toward hiring handicapped persons (Doctoral dissertation, University of Michigan, 1980). Dissertation Abstracts International, 41, 09A.

Poole, D. L. (1987). Competitive employment of persons with severe physical disabilities: A multivariate analysis. Journal of Rehabilitation, 53(1), 20-25. 
Rosenberg, M. (1965). Society and the adolescent self-image. Princeton, NJ: Princeton University Press.

Rosenberg, M. (1979). Conceiving the self. (pp.149-174) New York: Basic Books.

Rosenberg, M. \& Kaplan, H. B. (1982). Social identity and social context. In M. Rosenberg \& H. B. Kaplan (Eds.), Social psychology of the self-concept (pp.173-178). Arlington Heights, IL: Harlan Davidson.

Sampson, D. A. (1981). Getting that job: Concrete steps toward gainful employment. Proceedings of the Fourth National Conference: The Accessible Institution of Higher Education: Opportunity, Challenge, and Response by the Association on Handicapped Student Service Programs in Postsecondary Education held in Boston, Massachusetts July 13-17, 1981.

Schelly, C. (1990). Transition Services offers full support. OT Week. 35(4), 6-7.

Schriner, K. F. \& Roessler, R. T. (1990). Employment concerns of college students with disabilities: Toward an agenda for policy and practice. Journal of College Student Development, 31, 307-312.

Super, D. E., Starishevsky, R., Matlin, N., \& Jordan, J. P. (1963). Career development: Self-concept theory. NY: College Entrance Examination Board.

Weinberg-Asher, N. (1976). The effect of physical disability on self-perception. Rehabilitation Counseling Bulletin, 20, 15-20. 
Yerxa, E. J. (1992). Some implications of occupational therapy's history for its epistemology, values, and relation to medicine. American Journal of Occupational Therapy, 46,79-83. 
APPENDIX A

Questionnaire 
Name:

Major:

Age: Marital Status: Single Married Grad Divorced

Disability (primary):

How would you discribo your disability? _ Mild Moderate_Severe

Age at which you acquired the disability:

Answer the questions according to the response which best describes you.

1. Strongly agree 2. Agree 3. Disagree 4. Strongly disagree

1. I feel that l'm a person of worth, at least on an equal basis with others.

2. I feel that I have a number of good qualities.

3. All in all, I am inclined to feel that I am a failure.

4. I am able to do things as well as most other people.

5. I feel I do not have much to be proud of.

6. I take a positive attitude toward myself.

7. On the whole, I am satisfied with myself.

8. I wish I could have more respect for myself.

9. I certainly foel useless at times.

10. At times I think I am no good at all.

11. When I think about working, I don't feel very likeable.

12. When I think about working and I compare myself to others, I feel inferior.

13. When I think about working, all in all, I am inclined to feel that I am a failure.

14. When I think about working, I am unworthy of other people's attention.

15. When I think about working, I could never be as competent as most people.

16. When I think about working, I feel I do not have much to be proud of.

17. When I think about working, I wish I could have more respect for myseff.

18. When I think about working, I feel extremely inadequate in most situations.

19. When I think about working, I certainly feel useless at times.

20. When I think about working, at times I think I am no good at all.

21. When I think about working, I don't think I'll ever amount to much.

Answer the following questions:

1. Never/Rarely 2. Sometimes 3. Often 4. Usually/Always.

22. I have a lot of "stick-to-itiveness".

23. I am confident in my ability to get a job.

24. My attitude about myself is generally positive.

25. I feel my disability will prevent me from getting a job I want.

26. I am excited about my vocational future.

27. I keep plugging even though it looks like l'm not getting anywhere.

28. I am dissatisfied with myself.

Answer the following questions:

$\begin{array}{llll}\text { 1. Strongly disagree } & \text { 2. Disagree } & \text { 3. Agree } & \text { 4. Strongly agree. }\end{array}$

29. I have a great deal of self-confidence.

30. I am unsure about my plans for a job.

31. My disability will prevent me from obtaining a job.

32. I am clear what steps to take to get a job I want.

33. I know what kind of job I want.

34. I am not sure just how to prepare myself for the kind of job I should go after.

35. I can get a job.

36. I give up easily.

37. I am optimistic about my vocational future.

38. I know my abilities as a worker.

39. I am worried that I will not be able to get a job.

40. I am confident in my ability to get a job. 
APPENDIX B

Interview Questions 
1. Have you ever worked (prior or since you've acquired the disability)?

a) If yes: Briefly describe the type of jobs/job titles you have held.

b) What is the approximate length employed at each job?

2. Do you have volunteer work experience?

a) ...in your major or career interest (prior or since the disability)?

3. Have you taken career planning or job preparation classes in school or at work?

a) What did consist of?

b) Do you feel confident in writing a resume?

c) Do you feel confident in interviewing for a job?

4. What is your career goal?

a) What type of job do you plan to seek after you graduate?

b) Will it be in or outside of your major?

c) How successful will you be at achieving you goal? ( 1 low to 4 high)

5. Do you feel prepared/ well trained for the work you would like to do?

a) How might you be better prepared?

6. How confident are you about obtaining employment after graduation in the job you would like or in your major?

a)..on a scale: 1) not confident 2) somewhat 3) very 4) highly confident

b) Can you tell me why you feel confident about becoming employed? (What is it that makes you confident?)

c) Can you tell me why you do not feel confident about becoming employed?

7. Do you think you will have any difficulty in gettng a job as compared to other nondisabled/disabled graduates in you class or major?

a) 1) less difficult 2) same amount or 3) more difficult

8. What factors may assist you to become employed?

a) What factors may hinder you to become employed?

9. What barriers do you face in meeting your career goal? 
38

APPENDIX C

Consent Form 


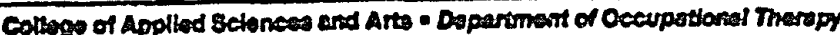

One Whathington Square - Sen Jood, Cartiomia $83192-0000$

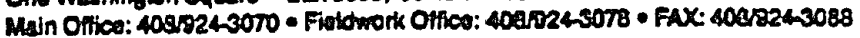

\section{AGREEMENT TO PARTICIPATE IN RESEARCH AT SAN JOSE STATE UNIVERSITY}

TITLE OF PROTOCOL: The relationship between vocational ideas and feelings and the perception of employablity of students with a physical disability.

I have been asked by Cathleen Marquez the responsible Investigator, to particlpate in a research study that Investigates my vocational ideas and feellings and my perception of becoming employed. The results of this study should further our understending of factors which may inhibit an individual from becoming employed.

I understand that:

1) I will be asked to corrpteto a questionnairo and in-person hiteniow in a testing room of corference room on campus. ( $45-60$ minutes)

2) the possible ristos of this study are minimal to none meaning that the probabilfy or magnitude of discemfort is no greater than ancourder in routins psychological examiniations or tosts.

3) the possible bonofits of this study to mo are an increased awarenoss of my ideas and lestings concarning work, my expectations of employability, and corvicas on campus which can assiat ma in obtaining my caroer goals.

4) the resulis from this study may bo pubrishod, but any information from this study that can bo identfied with me will remin confidential and will be disclosed only with my pormission.

6) any quastions about my participation in this study witbo answoned by Cethleen Marquar (408)9851088. Compkaints about the proceduras may bo preanted to Dr. Kay Schwart, Graduate Advisor, or Dr. Lola Llorens, Occupationsl Tharapy Departmont Chair, at 9243070 . For questions or complaints about research asjject's rights, or in the ovent of research-related injury, contect Sorena Stantord, Ph.D., Associato Academic Vice Prasident for Graduedo Studies \& Resareh, at 924-2480.

6) my consent is given voluntarily whthout baing cosced; 1 naty rofuse to participate in this study or in amy part of this sudy, and I may with draw an any tine, whithit projudico to my relations with SUSU.

7 i have recsived a copy of this consant form for my tha.

My signature indicates that I have read the information provided above and that I have decidad to participate.

\begin{tabular}{lc}
\hline Subjocts Signours & Deto \\
\hline Imestigator's Signatum & Deso
\end{tabular}

